Ганна Флейта

Гродна

\title{
Жанр трыялету ў паэзіі Гальяша Лейчыка і Алеся Петрашкевіча
}

Пачатак XX стагоддзя - гэта сапраўдная эпоха ў развіцці айчыннай літаратуры. Па назве галоўнага перыёдыка таго часу яго называюць "нашаніўскім". Як адзначыла вядомая даследчыца Ірына Багдановіч, ён быу у поўным сэнсе класічным перыядам беларускай літаратуры, паколькі ўсе сферы народнага жыция ўпершыню былі адлюстраваны $і$ ўвасоблены у прафесійнай выяўленчай $і$ рытміка-інтаначыйнай форме з апорай на папярэднюю фольклорную $i$ літаратурную традыцыю, а таксама з увагай да літаратурных набыткаў суседніх $і$ больш далёкіх культур ${ }^{1}$.

"Наша Ніва" займала важнае месца ў станаўленні беларускай літаратуры, была сапраўднай апорай для многіх пісьменнікаў-пачаткойцаў. Актыўна друкаваліся на старонках газеты будучыя класікі Янка Купала, Якуб Колас, Максім Багдановіч, Максім Гарэцкі і іншыя таленавітыя аўтары. У 1908 годзе ў рэдакцыю пачаў дасылаць свае вершы Гальяш Леўчык (Ляўковіч Ілья Міхайлавіч). Яго супрацойніцтва з газетай працягвалася да 1912 года.

Гальяш Лейчык праз усё жыциё шукаў шляхоў да красы, да гармоніi. Калі тое, што здавалася ідэалам, паварочвалася далёка не ідэальнымі гранямі, паэт скіроўваў на іншы шлях ${ }^{2}$. Краса і гармонія

1 Гісторыя беларускай лimapamypы: XIX - nачатак XX cm.: Падруч. Для філал. фак. пед. ВНУ. Пад агул. Рэд. М. А. Лазарука, А. А. Семяновіча, 2-е выд., дапрац., Мінск 1998, с. 181.

2 А. Петрушкевіч, Некаторья старонкі беларускай літаратурь пачатку XX стагоддзя, Гродна 2010, с. 95. 
- што можа быць важнейшым для паэта. I гэта адносіцца не толькі да Леўчыка, але і да іншых пісьменнікаў. Пошукі нечага ідэальнага, часам нават нерэальнага, часта захапляюць чалавека, а тым больш творчую асобу.

Паэт займаўся таксама перакладамі твораў польскай і сусветнай паэзіі. Засяродзімся на трыялетах, сярод якіх ёсць перакладзеныя з іншых моў. Трыялет "Жаваранкаў песні носяцца над нівай” з'яўляецца арыгінальным творам паэта:

Жаваранкаў песні носяцца над нівай.

Беларуса цяжкі раздаецца стогн -

Слёзна пот ліецца з галованькі сівай...

Жаваранкаў песні носяцца над нівай ${ }^{3}$

У ім аўтар апісвае становішча селяніна-беларуса, які вымушаны нават у сталым ўзросце цяжка працаваць, але гэта праца яго не абцяжарвае. Наадварот, чалавек старанна даглядае зямельку, якая корміць яго. У вершы мы сутыкаемся з кантрастам: побач з вобразам спрацаванага селяніна паўстае вобраз свабодных птахай, якія вольна лётаюць у чыстым небе і спяваюць свае песні:

Беларус не мае вольнае, шчаслівай

Бацькаўшчыны, толькі вузкі свой загон.

Жаваранкаў песні носяцца над нівай.

I ратай іх чуе, як прызыўны звон! (49)

Жаваранкаў песні носяица над нівай - гэтыя словы гучаць як npbзыўны звон для беларуса, як заклік да свабоды, незалежнасці. Трыялет напісаны шасцістопным харэем. Мае двайную рыфму: абаа абаб. Для большага эмацыянальнага ўзмацнення побач з эпітэтамі вольная, шчаслівая (Бацькаўшчына), выкарыстоўваецца вузкі (загон).

Гальяшом Леўчыкам быў складзены зборнік "Мудра прыгаворка соладка і горка", куды ўвайшло каля ста пяцідзесяці трыялетаў усходнеславянскай мудрасці. Але рукапіс не ўдалося выдаць i, за выключэннем некалькіх твораў, ён быў страчаны. Чатыры наступныя трыялеты, да якіх мы звернемся, з'яўляюцца перакладамі з японскай, арабскай і персідскай моў.

Верш "Як ты мудрэц - вучы другога" напісаны чатырохстопным ямбам. Аўтар плённа выкарыстоўвае гукапісны малюнак: часты

3 Г. Леўчык, Доля $і$ хлеб, [у:] Г. Леўчык, Выбраныля творы, склад. В. Саламевіч, Ляшковіч, Мінск 1980, с. 49. Далей пры спасылцы на гэта выданне ў дужках падаецца старонка. 
пайтор зычных гукай [д], [р] спрыяе адметнасці паэтычнага выказвання:

\author{
Як ты мудрэц - вучы другога: \\ вось гэта будзе труд галойны; \\ і лепш пайдзе жыцця дарога - \\ Як ты мудрэц - вучы другога (88).
}

Філасофска-гуманістычны змест трыялета яшчэ раз нагадвае нам аб ідэі ройнасці ўсіх людзей перад Богам:
Папраўдзе роўны ўсе ў Бога:
ўсім людзям свет сонца ройны -
Як ты мудрэц - вучы другога: вось гэта будзе труд галойны (88).

Аўтар звяртае нашу ўвагу на тое, што сонца свеціць для ўсіх і для кожнага. Няма чалавека, які б меў нейкія асаблівыя правы ці ўвогуле не меў бы іх. У сваім жыцці Гальяш Леўчык шукай мажлівасці даказваць такія ісціны. Лірычны герой апавядае нам пра мудраца, які яўна шмат ведае і многае перанёс у гэтым жыцці, але ён не павінен хаваць свае ўменні. Тройчы гучыць заклік як mы мудрэи - вучы другога. Яму надаецца асаблівае значэнне $\breve{y}$ тым плане, што гэта дапамога будзе ацэнена: Гэта будзе труд галоўньл. Таксама гэты заклік дапамагае ўсвядоміць тое, што людзі не павінны аддзяляцца адзін ад аднаго. Дапамога бліжняму прынясе толькі добрыя вынікі $i$ лепш пайдзе жыция дарога.

Звяртаючыся да наступнага перакладу "Перасцярогі не купіш на рынку", мы зноў сутыкаемся з філасофскай тэматыкай. Лірычны герой заклікае сына быць асцярожным у жыцці, таму што яно вельмі складанае і цяжкае. Якім бы чалавек ні быў: Ці мудрьл, иі часам дурнь тьл, мой сьлнку, // хоиь робіш мо спрьлтна і гладка (88), але заўсёды неабходна асцерагацца:

Перасцярогі не купіш на рынку,
на ярмарцы, быццам цялятка,
ці там ягнятка, ці мо як свінку,
перасцярогі не купіш на рынку (88).

Трыялет мае дзве рыфмы паводле сумяшчальнасці паэтычных радкоў. Першае чатырохрадкоўе мае кальцавую ці апаясаную рыфму, а другое - перакрыжаваную. Выкарыстаны памяншальна-ласкальныя формы назойнікай: цялятка, ягнятка, свінка. 
Гэтыя трыялеты, як і два наступныя, маюць дыдактычны, павучальны змест. У аснову кожнага з іх пакладзена вядомая прыказка ці прымаўка, альбо проста вядомае выслоўе. Трыялет "Мала варты кот такі" заснаваны на тым, што чалавек павінен у жыцці заранёў прадумваць свае крокі. Яму неабходна навучыцца бачыць праблему з ўсіх бакоў. Інакш можна прапусціць нешта вельмі важнае:

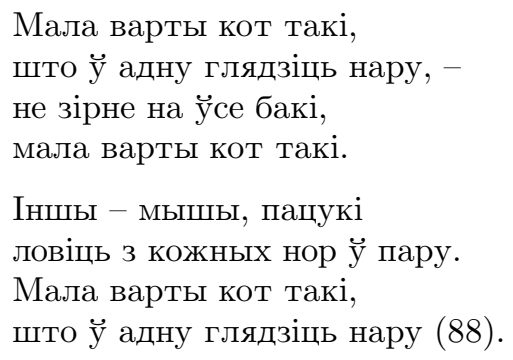

У вершы выкарыстана алегорыя, што дазваляе аўтару паказаць чалавека пад вобразам ката, што ў адну глядзіџь нару. Сэнс гэтай філасофіi жыццёвай мудрасці ў тым, каб важную праблему не разглядаць з аднаго боку, а шукаць іншыя шляхі для яе вырашэння.

У аснову трыялета "Хто ваўкой баіцца" легла ўсім вядомая прыказка: Ваўкой баяцца - у лес не хадзіць. Вось якое тлумачэнне дае ёй вядомы мовазнаўца, аўтар слойніка прыказак I. Я. Лепешаў: Вайкоў (ваўка, войка) баячиа - у лес не хадзіџь. Калі баячча ияжкасцей, небяспекі, то не варта і пачыначь што-небудзь ${ }^{4}$.
Хто ваўкоў баіцца, той ягнят патраціць, - воўк таму прысніцца, хто ваўкоў баіцца.
Як з ваўком пабіцца - смеласці не хваціць; хто ваўкой баіцца, той ягнят патраціць (89).

Сэнс гэтага трыялета $\ddot{y}$ тым, што калі чалавек баіцца нечага, то на яго жыццёвым шляху ўвесь час будуць з'яўляцца нейкія перашкоды і цяжкасці. Заўсёды патрэбна змагацца да канца і тады ўсё будзе вырашацца вельмі хутка і лёгка.

4 I. Я. Лепешаў, М. А. Якалцэвіч, Слойнік беларускіх прыказак, Мінск 2002, c. 81 . 
Адным з пачынальнікаў беларускага трыялету быў таксама паэт"нашанівец" Алесь (Ануфры) Петрашкевіч. Пра гэтага аўтара вядома вельмі мала. Небагатая і яго літаратурная спадчына: да нас дайшлі толькі тры трыялеты ягонага аўтарства. Але і яны, несумненна, вартыя ўвагі.

Верш "Хацеў бы ветру быць я братам" напісаны чатырохстопным ямбам. Мае наступную рыфму: абба ббаб.
Хацеў бы ветру быць я братам,
Гуляць, як ён, па свеце белым,
Быць шустрым, дзікім, ўсюды сьмелым
Хацеў бы ветру быць я братам 5 .

Алесь Петрашкевіч таксама не абмінуў філасофскую тэматыку. Лірычны герой верша дзеліцца з намі сваімі жаданнямі і марамі. Вобраз ветру звычайна сімвалізуе свабоду і незалежнасць, якое так прагне лірычны герой. Ён марыць “быць шустрыл, дзікім, ўсюды смельм", “гудзець над борам застарэльл". У прыгнечаным краі цяжкае жыццё, а вецер можа гуляиь па свеце бельм:

Гудзець над борам застарэлым,

Над краем песьні пець заклятым,

Хацеў бы ветру быць я братам,

Гуляць, як ён, па свеце белым ${ }^{6}$.

Закляты край - на гэты вобраз, зразумела, найперш звяртаецца ӱвага. Аўтар выдатна ведаў, у якім стане знаходзіцца родны край і не мог маўчаць. Тым больш, што побач ёсць бель свет - вялікі, вольны, незалежны. Вобраз ветру выкарыстаны аўтарам недарэмна, бо менавіта праз яго лепш за ўсё можна перадаць імкненне да волі, свабоды, незалежнасці.

Трыялет "Калісь і я сасе быў брат" прымушае нас задумацца над тым, якое месца чалавек займае $\ddot{y}$ гэтым жыцці. Маналог лірычнага героя адлюстройвае стан душы народа. Заўсёды на першым месцы у беларускага селяніна была зямелька, якая яго карміла:

Калісь і я сасе быў брат,

3 ей часта ў полі дні праводзіӱ,

Шукай там долі - й ня знаходзіў,

Калісь і я сасе быў брат.

\footnotetext{
5 А. Петрашкевіч, Хацеў бы ветру быць я братам, "Наша Ніва", штотыднёвая газета, № 41, 1913, Факсімільнае выданне, Мінск 2009.

6 Тамсама.
} 
Ды ўжо разстаўся: сьвет сазводзіў

Цяпер успомніць толькі рад:

Калісь і я сасе быў брат,

3 ей часта ў полі дні праводзї̈̆.

Лірычны герой ияпер успомнічь толькі рад аб той цяжкай працы, якая засталася недзе далёка.

Наступны трыялет адрозны ад папярэдніх тым, што тут закранута тэма мастака і мастацтва. Герой гаворыць пра "ахвяры" (свае творы), якія ён паклаў на "ахвярнік" (падразумяваюцца творчасць, мастацтва). Мастак звяртаецца да тых, хто прыняў і палюбіў яго "песьні". Таму для іх яго "ахвяры” недарэмныя.

I мой ахвярнік не астыў.

Гарыць ешчэ агонь на ім

І рвецца ў горку сіні дым...

I мой ахвярнік не астыў,

Магу сказаць во гэта ўсім,

Хто мае песьні палюбіў:

I мой ахвярнік не астыў, -

Гарыць ешчэ агонь на ім ${ }^{8}$.

Два апошнія трыялеты напісаны чатырохстопным ямбам. Маюць дзве рыфмы: абба бааб.

Трыялеты Гальяша Леўчыка і Алеся Петрашкевіча блізкія сваім пафасам, магчыма, таму, што пісаліся яны ў адзін час і аўтараў хвалявалі прыкладна аднолькавыя праблемы. Прыведзеныя вершы Гальяша Леўчыка, як ужо адзначалася, у аснойным дыдактычнага зместу. Яго, відаць, цікавіла паэзія іншых народаў, таму ён і рабіў пераклады. Алесь Петрашкевіч быў у сваёй творчасці бліжэй да народных вытокай. Паэт выкарыстай форму трыялета, каб адлюстраваць тэму мастака і мастацтва.

Творчасць Гальяша Леўчыка, Алеся Петрашкевіча і іншых "нашаніўцаў” - гэта цікавая старонка айчыннай літаратуры, якая яшчэ доўгі час будзе прыцягваць увагу даследчыкаў.

\footnotetext{
7 "Наша Ніва", № 48, 1913.

8 "Наша Ніва", № 1, 1914.
} 
S T R E S Z C Z E N I E

\title{
TRIOLET W POEZJI GALIASZA LEWCZIKA \\ I ALESIA PIETRASZKIEWICZA
}

Trudno przecenić rolę gazety „Nasza Niwa” w procesie kształtowania się literatury białoruskiej czasów najnowszych. Oprócz przyszłych klasyków na stronach gazety swoje teksty publikowało wielu autorów, których twórczość zasługuje na szczególną uwagę. Galiasz Lewczik nie tylko sam pisał triolety lecz także tłumaczył je z innych języków. gatunek ten zajmował też istotne miejsce w twórczości Alesia Pietraszkiewicza. W artykule omówiono triolety w poezji Galiasza Lewczika i Alesia Pietraszkiewicza. Wskazano na dydaktyczny charakter utworów G. Lewczika i zbliżenie do narodowych źródeł trioletów A. Pietraszkiewicza

Słowa kluczowe: literatura białoruska, „Nasza Niva”, triolet, bohater liryczny, dydaktyzm, artysta i sztuka.

\author{
S U M M A R Y \\ THE TRIOLET IN GALYASH LYEVCHIK'S AND \\ ALES PYETRASHKYEVICH'S POETRY
}

The role of "Nasha Niva" newspaper in the development of Belarusian literature in modern time cannot be underestimated. In the newspaper texts of past and future authors are published. Galyash Lyevchik wrote triolets and translated them from other languages. The genre of triolet occupied an important place in Ales Pyetrashkyevich's poetry. The article discusses Galyash Lyevchik's and Ales Pyetrashkyevich's triolets. Didactic character of Lyevchik's poetry and national values of Pyetrashkyevich's triolets are emphasized.

Key words: Belarusian literature, "Nasha Niva", triolet, lyrical hero, didacticism, artist and art. 